\title{
Use of Geographical Information Systems for billboards and points-0f-sale surveillance in two Mexico cities
}

\author{
Juan Eugenio Hernández-Ávila, M en C,(1) Enrique Tirado-Ramírez, L en Plan Terr, (') René Santos-Luna, Ing Elec, (I) \\ Luz Myriam Reynales-Shigematsu, MD, M en C, Dra en C.(I)
}

\begin{abstract}
Hernández-Ávila JE,Tirado-Ramírez E, Santos-Luna R, Reynales-Shigematsu LM. Use of GIS for billboards and points-of-sale surveillance in two Mexico cities.

Salud Publica Mex 2007;49 suppl 2:S24I-S246.
\end{abstract}

\begin{abstract}
Objective.To assess the degree of compliance with current legislation using Geographic Information Systems. Material and Methods. Schools and billboards advertising tobacco were geo-referenced and the distance to schools were measured. Students' access to purchasing tobacco products was observed. Results. In Cuernavaca, billboards were found within 250 meter from schools and students had access to buying cigarettes. In Culiacan, students were less exposed to tobacco advertising. Conclusions. Geographic Information Systems were useful for studying compliance with the law and could also be useful for its continuous monitoring and for suggesting changes for diminishing tobacco advertising exposure. This exposure and the ease of access to purchasing cigarettes could explain the higher prevalence of active smokers among students in Cuernavaca. This suggests that current legislation is still not enough enforced for diminishing Mexican adolescents' exposure to tobacco advertising and products.
\end{abstract}

Key words: tobacco control; surveillance; geographical information system (GIS); Mexico
Hernández-Ávila JE,Tirado-Ramírez E,

Santos-Luna R, Reynales-Shigematsu LM.

Vigilancia de la propaganda de los productos del tabaco en espectaculares y en puntos de venta en dos ciudades de México usando un Sistema de Información Geográfica (GIS). Salud Publica Mex 2007;49 supl 2:S24I-S246.

\section{Resumen}

Objetivo. Determinar el grado de cumplimiento de la legislación y su impacto mediante la utilización de Sistemas de Información Geográfica (GIS). Material y métodos. Se georreferenciaron escuelas y espectaculares con propaganda de tabaco en Culiacán y Cuernavaca. Se midió la distancia a las escuelas. Se observó si los estudiantes tenían acceso a comprar productos de tabaco. Resultados. En Cuernavaca se encontraron espectaculares a $250 \mathrm{~m}$ de escuelas. Los estudiantes tenían acceso a adquirir productos del tabaco. En Culiacán los estudiantes estuvieron menos expuestos a propaganda y productos del tabaco. Conclusiones. Los GIS fueron útiles para estudiar la observancia de la legislación actual y podrían serlo para monitorear su cumplimiento, así como para sugerir modificaciones que disminuyan la exposición a la propaganda de tabaco. Esta exposición y la facilidad para adquirir cigarrillos podrían explicar la prevalencia de fumadores activos más elevada en los estudiantes de Cuernavaca. Esto sugiere que la legislación vigente no es suficiente para la disminución de la exposición de los jóvenes mexicanos a propaganda y productos del tabaco.

Palabras clave: control de tabaco; vigilancia; sistemas de información geográfica (GIS); México

(I) Instituto Nacional de Salud Pública. México.

Received on: April 4, 2007 - Accepted on: April 30, 2007

Solicitud de sobretiros: Mtro. Juan Eugenio Hernández-Ávila. Instituto Nacional de Salud Pública. Av. Universidad 655,

Col. Santa María Ahuacatitlán. 62508, Cuernavaca, Morelos, México.

Correo electrónico: juan_eugenio@correo.insp.mx 
T he results of the Global Youth Tobacco Survey in Mexico show that the prevalence of active smokers in a representative sample of 42024 adolescents 12 to 15 years of age from 492 secondary schools during 2003 to 2005 was $19.96 \%$. Sixty percent of smokers had access to cigarettes regardless of their age and $86 \%$ had seen cigarette advertising in the previous month. It is no wonder that adolescents are starting to smoke at 11 or 12 years of age. ${ }^{1,2}$ Maybe the most distinctive feature of the tobacco epidemic in Mexico is that the starting ages, as well as the prevalence of smoking for men and women, are similar across the country.

Cigarettes are one of the most heavily advertised and promoted products in many parts of the world; Mexico is no exception. Tobacco companies claim that the advertising is directed to adults and to promote brand loyalty or switching, but there is now a large amount of literature that links this advertising to adolescent cigarette smoking. Breslau and Peterson have pointed out that the starting age for smoking is a determinant factor in the probability of cessation. ${ }^{3}$ The odds of quitting for smokers that started after 13 years of age were higher than for those who started before 13 years old, and these odds increased as the age for starting increased. It is therefore of utmost importance to stop the tobacco industry from targeting children for advertising and promotion of cigarette smoking.

In May 2003, the member states of the World Health Organization (WHO) agreed upon a public health treaty to control tobacco supply and consumption: The WHO Framework Convention for Tobacco Control (FCTC). It covers tobacco taxation, smoking prevention and treatment, illicit trade, advertising, sponsorship and promotion, and product regulation. This framework was signed by Mexico in April 2004 and ratified in May 28th 2004. The FCTC sets the guidelines for the development of laws to slow down the tobacco epidemic. As a signatory country, Mexico has already implemented actions to control tobacco advertising, including a law passed by congress in October 2000 prohibiting tobacco advertising on radio and television, as well as on internet sites. This law also banned tobacco advertising on billboards within a 250 meter radius around schools, up to and including high school education, as well as near hospitals, recreational parks and other sports and family centers.

A pilot project was carried out in a sample of schools in the cities of Cuernavaca, Morelos and Culiacán, Sinaloa between November 2005 and January 2006 to investigate the feasibility of using a Geographic Information System (GIS) for determining the extent to which tobacco industries in Mexico are complying with the tobacco advertis- ing law and to assess its impact on the prevalence of active teenage smoking in secondary schools.

A geographic information system is a set of computer tools to enter, edit, display, manage and analyze data with spatial reference, such as the location of schools and billboards. It also provides tools to manage and analyze related data such as number of students per school and type of advertising. Geographic information systems and analyses based on their use have become more and more common in the field of public health and can be used as an important way to understand how humans interact with their environment. ${ }^{4,5}$ Although many of the applications are related to environmental studies and the assessment of exposure levels, other applications have explored the realm of health systems and access to health services. ${ }^{6,7}$ In addition, closely related to the present work, Luke, Esmundo and Bloom ${ }^{8}$ used GIS to assess the extent to which tobacco companies were locating billboards in close proximity to minority neighborhoods and to schools in the San Louis metropolitan area.

GIS tools can be used to monitor tobacco advertising in the vicinity of schools and compliance with the current legislation, which can also be used to support the development of new laws for decreasing the level of exposure of students to tobacco advertising.

In view of the potential benefits that GIS can bring to public health analysis, the Department of Informatics and Medical Geography at the National Institute of Public Health (INSP for its initials in Spanish) developed and maintains a GIS with national data on health and health related data, such as the geographical distribution of mortality, morbidity, health care infrastructure, and demographics and socioeconomic characteristics of the Mexican population. Cartographic information such as urban trace for more than 18000 localities, digital elevation models, aerial photography and satellite images can also be found in this GIS, which served as a starting point for the development of this project. This GIS can be freely accessed at http: / / naais.insp.mx.

\section{Material and Methods}

This is a study case for evaluating the feasibility of using a GIS to determine the degree of compliance with the tobacco advertisement law and its impact on secondary school students in the cities of Cuernavaca, Morelos and Culiacan, Sinaloa, by observing billboard and / or tobacco advertising at points-of-sale and relating it to the results of the Global Youth Tobacco Survey. The project was carried out between November 2005 and January 2006. The cities of Cuernavaca and Culiacan were selected for con- 
venience to minimize costs. Culiacan was selected due to the fact that one of our field teams was scheduled to validate, with GPS equipment, the urban cartographic information for that city and the National Institute of Public Health is located in Cuernavaca.

Schools: A random sample of schools participating in the Global Youth Tobacco Survey in the cities of Cuernavaca and Culiacán was selected to be geocoded by address and incorporated into the GIS. Addresses of the selected schools were obtained from the public website managed by the Ministry of Education.

Billboards: Billboards were defined as outdoor stationary structures upon which tobacco advertising was posted, including elevated signs and signs attached or painted to the side of buildings.

Points of sale: Points of sale were defined as supermarkets, convenience stores, gas stations, small retail outlets, tobacco stores, liquor stores and street vendors.

Study areas: A 500 meter buffer around the schools was constructed using the GIS to delimit the study area for each school.
Field work: A printed map of all schools and their surroundings was produced to help field personnel find the schools (Figure 1). All billboards and points-of-sale within the schools' study areas were geo-referenced using a GPS device. We also asked the field personnel to draw the location of billboards and points-of-sale on the printed maps as a way to verify the information and to evaluate the possibility of eliminating the use of GPS (as a way to lower costs) for a larger study by simply incorporating them in the GIS by digitizing them on the screen based on the paper map.

An instrument was developed to observe exterior advertising (billboards) and the line of view from the school entrance. Another instrument was developed for recording information about advertising strategies at the points-of-sale. At each point-of-sale, promotional information and settings offering cigarettes were observed and recorded. In addition, field personnel asked about prices by the pack and carton of cigarettes.

The team spoke with school authorities, identifying themselves as workers from the National Institute of

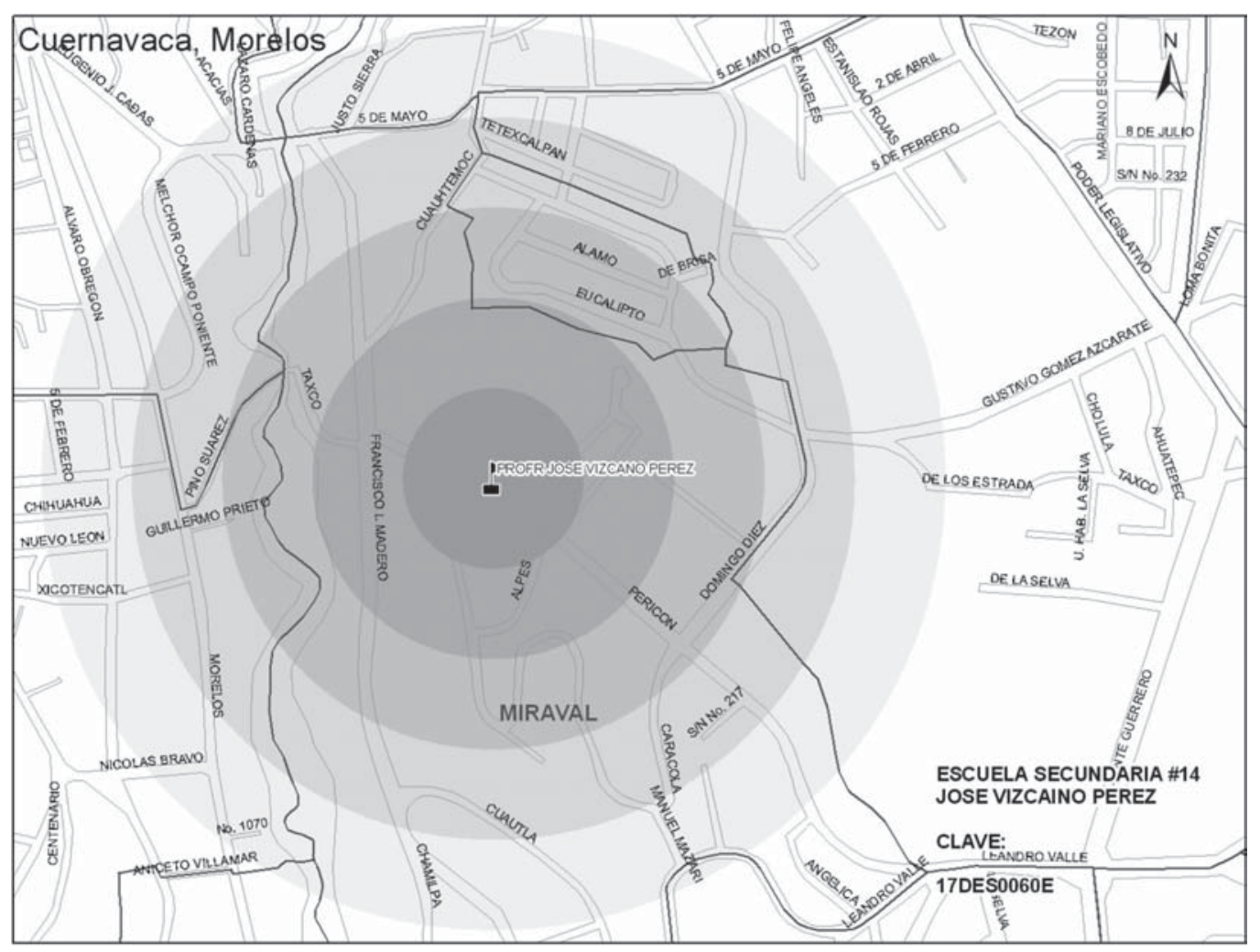

Figure I. Field map of the study area of a school in Cuernavaca 
Public Health, in order to be allowed to photograph the schools and their surroundings at the time the students were leaving. The behavior of the students was observed as they got out of the schools and started on their way back home.

\section{Results}

A total of 33 schools were visited, 20 in Culiacan and 13 in Cuernavaca. Eighty percent were in urban areas in Culiacan and 69\% were in urban areas in Cuernavaca. Thirty-one percent of the schools in Cuernavaca were private and $100 \%$ in Culiacan were public. No billboards were found that advertised tobacco products in the study areas of the schools in Culiacan, but they were found in Cuernavaca. There was as much as twice the number of points-of-sale in Cuernavaca compared to Culiacan, even though more schools were visited in the latter (Figure 2 and 3). Also, no tobacco advertising and no street vendors were observed in the exterior of the points-of-sale in Culiacan, as opposed to Cuernavaca where they were observed.
The general behavior of students leaving the school varied by type of school and also by the presence, or not, of uniformed police surveillance. In private schools, all students were orderly escorted to a relative who came to pick them up and so none of them stayed in the surroundings of the school. In public schools, the students gathered in the surroundings of the school, along with other adolescents not from the school, some of who were smoking. The presence of uniformed police determined the amount of time the students took to disperse and their general behavior. It also determined where street vendors sell single cigarettes and their location with respect to the school entrance. In general, compliance with advertising laws was observed to be higher in Culiacan than in Cuernavaca (Table I).

In Cuernavaca, students often did not present identification when purchasing cigarettes, they had the option to buy single cigarettes, and they were exposed to tobacco propaganda inside stores and through the use of illegal billboards within 250 meters of the schools. In Culiacan, there was less tobacco propaganda compared to Cuernavaca, possibly because Culiacan schools were

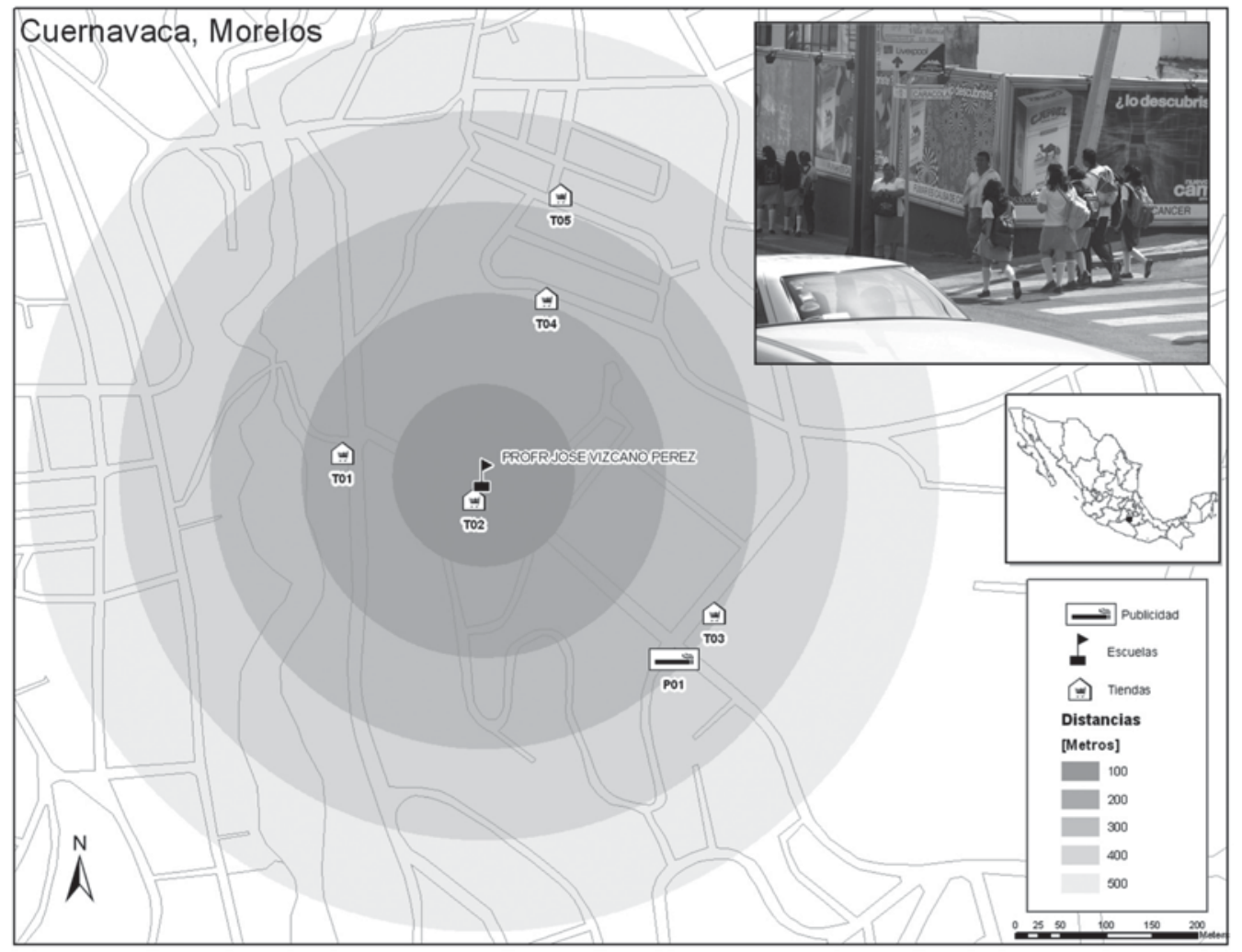

Figure 2. Results in Cuernavaca. Students are exposed to tobacco advertising as they leave the school 


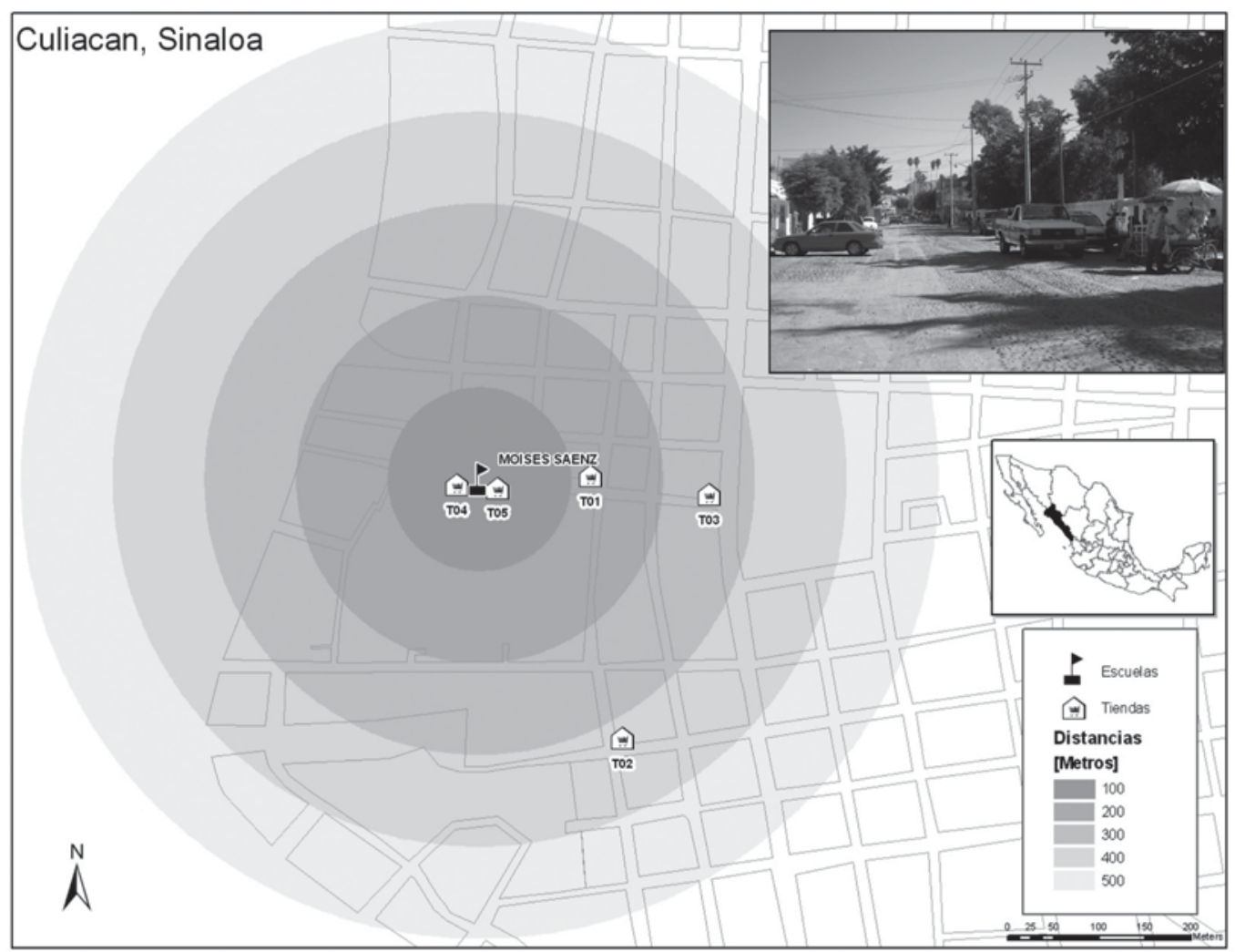

Figure 3. Example of results in Culiacán. No exposure to tobacco advertising

located in non-commercial areas. This correlates with the GYTS survey findings showing that $21.3 \%$ of the students in Cuernavaca and $10.8 \%$ in Culiacan were active smokers.

\section{Discussion}

Geographic information systems have been successfully used to assess exposure levels to environmental pollutants in many settings, ${ }^{910}$ and to map and measure the level of exposure to tobacco advertising in urban areas. ${ }^{8}$ The use of geographic information systems in this project was successful. It was used to map the amount of tobacco-related advertising in the vicinity of secondary schools. Both the use of GPS and the direct digitizing from the printed field maps were adequate for the purposes of the project; the latter could be used to optimize resources in future work around the world as part of a compliance surveillance tool. The Department of Medical Geography and Informatics at the National Institute of Public Health has experience working with GIS tools for the purpose of assessing the coverage of the Ministry of Health hospital system. ${ }^{6}$ Recently, we have developed web-based GIS tools to geocode water quality in households based on addresses. This tool is now being used by the Federal Commission for Sanitary Risk Protection (Comisión Federal de Protección contra Riesgos Sanitarios, COFEPRIS)

A similar tool could be used to promote civil participation in the creation of geocodes for all tobacco-related billboards.

The results of this project also show that in the city where there was less exposure to tobacco advertising in the vicinity of schools and less access to tobacco products, the prevalence of active smokers was lower among secondary school students. Although this is a pilot project, it supports the idea that tobacco advertising is targeting the adolescent population; this, in-turn, supports the decrease in the age at which children start smoking.

The current legislation is still not enough enforced to diminish the exposure of students in secondary schools to tobacco advertising. The observations in the present study show that, in spite of the fact that the billboards are 
Table I

SUMMARY OF OBSERVED VARIABLES RESULTING FROM the Global Youth Tobacco Survey. Mexico, 2003

Observation

Culiacán Cuernavaca

Total secondary schools

\begin{tabular}{lrc} 
Total secondary schools & 20 & 13 \\
\hline Urban & 16 & 9 \\
\hline Rural & 4 & 4 \\
\hline Public & 20 & 9 \\
\hline Private & 0 & 4 \\
\hline Point-of-sale & 61 & 102 \\
\hline Billboards in the vicinity of schools & No & Yes \\
\hline External advertisement at points-of-sale & No & Yes \\
\hline Internal advertisement at points-of-sale & Yes & Yes \\
\hline Single cigarette sale & No & Yes \\
\hline Students smoking in the vicinity of schools & No & Yes \\
\hline External adolescents smoking in the vicinity of school & No & Yes \\
\hline Street vendors & No & Yes \\
\hline Presence of uniformed police when students leave & No & Yes
\end{tabular}

more than 250 meters away from school entrances, they are strategically located along the paths that students walk to go home. In addition, tobacco advertising was found in places where students wait for the bus, and at outside points-of-sale. Around some schools in Cuernavaca, students had access to purchasing individual cigarettes. This suggests that further work has to be done in terms of the revision of the laws for protecting students from exposure to tobacco advertising as well as their enforcement.

\section{References}

I.Valdés-Salgado R, Thrasher J, Sánchez-Zamorano LM, Lazcano-Ponce E, Reynales-Shigematsu LM, Meneses-González F, et al. Los retos del convenio marco para el control del tabaco en México: un diagnóstico a partir de la Encuesta sobre Tabaquismo en Jóvenes. Salud Publica Mex 2006;48:5-16.

2. Campuzano-Rincón JC, Hernández-Avila M, Sammet JM, MéndezRamírez I,Tapia-Conyer R, Sepúlveda-Amor J. Comportamiento de los fumadores en México según las Encuestas Nacionales de Adicciones 1988 a 1998. In:Valdés-Salgado R, Lazcano-Ponce EC, Hernández-Avila M. Primer informe sobre el combate al tabaquismo. México ante el Convenio Marco para el Control del Tabaco, México. Cuernavaca: Instituto Nacional de Salud Pública, 2005.

3. Breslau N, Peterson EL. Smoking cessation in young adults: age at initiation of cigarette smoking and other suspected influences. Am J Public Health 1996;86:214-220

4. Ricketts TC. Geographic information systems and public health. Ann Rev Public Health 2003;24:I-6.

5. Cromley HK, McLafferty SL. GIS and public health. New York:Guilford, 2002;15-38.

6. Hernández-Avila JE, Rodríguez MH, Rodríguez NE, Santos R, Morales E, Cruz C, et al. Cobertura geográfica del sistema mexicano de salud y análisis espacial de la utilización de hospitales generales de la Secretaría de Salud en 1998. Salud Publica Mex 2002;44:5 19-532.

7. McLafferty SL. GIS and health care.Ann Rev Public Health 2003;24:25-42. 8. Luke D, Esmundo E, Bloom Y. Smoke signs: patterns of tobacco billboard advertising in a metropolitan region. Tob Control 2000;9:16-23. 9. Brody J, Melly S, Rudel R, Maxwell N. GIS exposure assessment for pesticides and drinking water in the Cape Cod breast cancer and environment study. Epidemiology 2000; I I:102.

10. Josef C, Matthias H, Ulrike G, Hoek G, Diegmann V, Brunekreef B, et al. GIS-based estimation of exposure to particulate matter and $\mathrm{NO}_{2}$ in an urban area: Stochastic versus dispersion modeling. Environ Health Perspect 2005; I 13: 987-992 